\title{
11
}

\section{ENACTING POLITICS WITH MOSQUITOES}

\section{Beyond eradication and control}

\author{
Jean Segata
}

It was 2016. I was researching public health policy for dengue fever among mosquito workers in Brazil's coastal city of Natal. But there were more diseases there than just dengue. It was also the time of Zika and chikungunya, and that early fall, locals were also sharing pictures of dead monkeys. On WhatsApp and Facebook, news was spreading as quickly as the viruses. Many people were confused. They talked about yellow fever too, and truths about all these diseases were mixed with half-truths. ${ }^{1}$

Little monkeys lived in the parks, stealing the tourists' food and posing for selfies with them. The precise number of monkey deaths was unknown, and workers could not reach a consensus about precise numbers. On social media, people spoke of more than 100 deaths; Lucas, a young mosquito worker, spoke of 40; and Carlos said there are only a half dozen. Lucas warned us that the monkeys' deaths were probably caused by yellow fever, but Carlos cautiously disagreed, saying he would rather wait for new tests being carried out at the Evandro Chagas Institute in Belém do Pará, a leading research centre since the days of the Rockefeller Foundation in Brazil. Local health officials had technologies to monitor mosquitoes and ill people, but it had no means by which to map yellow fever's virus. Amid uncertainties, I asked them, "Is there yellow fever here?" Both looked at each other, and Carlos replied:

We have no budget for yellow fever, and I don't even know if we could deal with a new epidemic. We've already had a lot of trouble with dengue, Zika and chikungunya-so yellow fever too? We must tweak the numbers. There is the tourism; there are vaccines. We have to think about everything. Let me explain: we'll develop a project to request funding to make the epidemic, and send it to the Ministry [of Health]. In the report we'll put in some pictures of monkeys and show their tests, and explain the troubles 
we've been having with mosquitoes. And let's hope they approve it. So, we will install the epidemic, you understand? If we are then rolling in money, we'll have a yellow fever epidemic, and whatever else you want ... But I don't know. The summer is over and the mosquitoes didn't help us. I hardly saw any. And now, with all this trouble in Brasília, I don't know ... Maybe the epidemic will happen only next year or never. No one knows.

I did not know what to say when I heard that answer. Carlos knew what he was talking about. In Natal, the battle against dengue was already permanent, having constituted a state of emergency for at least 30 years. Mosquitoes shaped all those diseases, and Carlos had made his career confronting all of them (Segata 2017, 2019). Local newspapers would refute rumours of yellow fever with claims that it was all fake news. But a few months later, dead monkeys were reported in Minas Gerais, São Paulo, Rio de Janeiro and Bahia as well. Trying to downplay the problem, the authorities said it was a kind of jungle yellow fever. But in the spring of 2017 people began to die across the country. Many wondered whether the disease was returning.

This chapter explores human-mosquito relations in the context of public health policies for epidemics: some of these relations are complex and go beyond the simple eradication or control of mosquito populations. Although such control programmes are being updated with new epidemiological knowledge, there are recalcitrant political frameworks that must be considered. Efforts to eradicate or control mosquito epidemics cost lives and bring suffering since people and mosquitoes alike resist top-down political machinations. Relations between humans and this insect go beyond eradication and control, producing complex political encounters and negotiations.

The first part of this chapter summarizes two different experiences from fieldwork in Natal and Porto Alegre, Brazil, highlighting the use of new digital and health technologies in monitoring and controlling mosquitoes as well as the people living with them. For more than a century, the Aedes aegypti mosquito was known as one of the main vectors of such diseases as yellow fever, dengue and more recently Zika and chikungunya. The mosquito's worldwide distribution puts it at the crossroads of global health science, politics and capitalism. Aedes aegypti is the harbinger of epidemic risk, in all its aspects. Not only do viruses travel with it, but knowledge, technology and material opportunities travel along as well: from international parameters defined by experts in the World Health Organization, to those who offer new perceptions of nature, or else represent financial interests of chemical industry shareholders at the World Bank. Local programmes for mosquito control have therefore been aligned with the interests of global health and its political connections to security. But things do not always work as imagined. The following descriptions show how fragile these local projects are and demonstrate ways such projects leak into global technologies and institutions. 
The second part of this chapter explores ambivalences between new epidemiological knowledge supported by digital-biological technologies and old epidemiological knowledge represented by the framework that organizes policies of mosquito epidemics. In recent decades, epidemics have been straining global health guidelines, which have increasingly invested in predictive technologies over preventive medicine, in a broader set of so-called preparedness and response policies (Collier \& Lakoff 2008, Reis-Castro \& Heidrickx 2013, MacPhail 2014, Nading 2014, Caduff 2015, Lakoff 2017, Keck 2020). The maxim of this understanding can be summed up in the idea that it is no longer a question of whether a pandemic is going to happen or not. The experts predict pandemics will happen, and the question is then to know when and whether we shall be prepared for them. However, it is also necessary to realize that the focus of these policies is not new, especially in the context of mosquito epidemics. For this reason, I take up how current ethnographic situations can be compared to their historical counterparts, to show how certain "preparedness and response" mechanisms are actually militarized mosquito-centric approaches that preserve social inequality. Nonetheless, some new technologies facilitate human-mosquito interactions and help the people involved to construct a common political infrastructure. ${ }^{2}$

My goal in this chapter is to show that since colonial times, the project of hiding tropical epidemics has largely been a broad machination of government. This works through a tropical unconsciousness. When risks and uncertainties are enacted, new discourses, institutions and technologies are then triggered in attempts to contain them. Mosquito eradication and control programmes serve to control and repress the lives of those they mean to save. In the end, people and mosquitoes are resistant to these top-down political pressures. Both are unruly. Both are beyond control.

\section{Natal and the digital mosquitoes}

"Here, everything is digital, even mosquitoes," said Lucas about the new approach to monitoring dengue epidemics in Natal, named vigi@dengue. Using traps scattered throughout the city and having an "at" in its name, this digital tracking system aimed to produce a high-tech update on local public health policy (Natal 2015).

Entomological data from the traps is combined with epidemiological data provided by the local healthcare system, detailing the exact location of people either sick with dengue or suspect of being infected by the virus. Cross-checking the locations of notified patients and mosquito eggs found in the traps indicates virtual territories of risk on the city map.

Coloured circles that vary from white to red according to the "danger," highlight potential areas of risk. The epidemic risk is an imaginary value calculated by the virtual presence of mosquitoes and sick people in the same space. Red circles are designated as "combat zones," in which mosquito workers are supposed to take a series of measures required by the Ministry of Health (Brasil 
2005, 2009). These measures include using pesticides to combat mosquitoes inside houses and other private properties. Aedes aegypti is the enemy; workers must visit all residences, check for breeding places, and eliminate them (Segata 2016a, 2016b, 2017).

Public health policymakers used to say that with technology, one can run but never hide: for them, vigi@dengue creates a sense of omnipresence and effectiveness. Indeed, technocratic fantasies about real-time monitoring have recently become a trend in epidemic surveillance systems (Caduff 2014a, 2014b, 2015, Lakoff 2015, 2017, MacPhail 2014). New digital technologies promote trust in more precise identification of risks and their control. The problem is that humans and mosquitoes do not always behave like binary codes.

The vigi@dengue was inaugurated in late 2015. Local newspapers praised the programme, heralding that the city was finally armed against the mosquito. The programme managers were already talking about delegations of politicians coming from other cities and districts interested in learning about it. Some of the mosquito workers, however, were less enthusiastic. Indeed, the project had some problems. They usually complained that "working with mosquitoes is not easy."

The first problem is that vigi@dengue's software receives inconsistent data, caused mainly by under-reporting of disease cases. Since access to medical services may be difficult in Brazil (Biehl et al. 2012, Biehl 2013), many ill people in Natal did not even bother to seek professional medical treatment, complaining about delays in care and the lack of proper care. Instead of waiting in long lines at the hospitals, they went directly to pharmacies. When someone caught dengue, Zika or chikungunya, the common treatment was simply to stay home, drink more water and treat symptoms such as temperature and pain with home remedies. Such patients went "under the radar" of the health system, and their cases were not included in the data.

A second problem is the weak correlation between infections data and mosquito data. Most of the information comes from the perspective of entomology overestimating the presence of mosquitoes. Epidemiological data considers patients' home addresses, but people can be bitten anytime and everywhere, whether at work, while commuting, or at leisure time (Segata 2017, 2019). The "enemy" does not always live in one's backyard.

A third problem is that the number of mosquitoes is estimated according to the quantity of eggs found. The number of eggs, in turn, is figured out by the surface these occupy on the trap, since mosquito eggs are too small to be numbered. As Lucas says, "you must have a manha," with manha being slang for a kind of skill acquired in daily experience. "Mosquito eggs look like ground coffee," he said. "You only give a peek, and kick a number." Official reports constantly claim that $90 \%$ of eggs are those of Aedes aegypti, although this is not tested. Additionally, eggs are not checked for the presence of viruses. All such estimates are built on the assumption that the presence of mosquitoes in a certain area is sufficient to explain the incidence of the disease. The keyword in this game is probability - what philosopher Ian Hacking (2002) defined as a kind of 
"guide to life" which never freed itself from subjective functions of interpretation and belief. Probability is not a method, but is aimed at a goal, supported by the empowerment of numbers. Similarly, entomological data derived from the vigi@dengue's algorithm came from a mix of practice, sensitivity, popular mathematics and haste. Sometimes, the accuracy of computational calculation must count on luck (Segata 2017).

\section{Prophets of Porto Alegre}

It was Friday and everything seemed calm in the Vectors and Rodents Office of the Porto Alegre Department of Health. As we were talking about the unstable weather, the low number of mosquitoes and the uncertainty about renewing the contract with the company conducting mosquito DNA tests, the phone rang. Ligia answered, and after listening silently for a while she pulled out the computer screen to check some maps. Following a short conversation, she hung up the phone and explained that people were calling to report mosquitoes in their vicinity.

People find mosquitoes in their house or on a nearby street and complain. But we know something about mosquitoes, and monitor everything ... In the past, people were moving from door to door applying poison and killing mosquitoes wherever they could find them, but now we try to find out if they are dangerous or not ... So you don't need to worry: if they don't carry a virus, they don't have a disease. Most mosquitoes are healthy. We have to learn to live with them, not all of them are bad.

(Ligia, Public Policy Manager, Municipal Health

Department. Porto Alegre, April 2017)

"Creating a new concept is part of the job," Ligia said, ending the conversation by complaining that "working with people is not easy." She argued that people assume that mosquitoes are not monitored nor does the department know which ones are infected. The popular belief was that the authorities were lying, and that nobody cares about their complaints.

Public authorities use modern technologies in Porto Alegre as well, but there they use traps to catch adult mosquitoes for DNA mapping rather than relying on eggs (Vargas 2018, Segata 2018a). More than 1,200 traps are set and geolocated, each carrying a QR code to identify it (Figure 11.1). Mosquitoes caught in them are mailed on a weekly basis to Belo Horizonte, as each mosquito sample corresponds to a specific trap. Their DNA is sequenced using PCR (polymerase chain reaction) technology, and when a virus is detected, the laboratory in Belo Horizonte warns the Department of Health in Porto Alegre. This data enables the Department of Health to locate infected areas (Figure 11.2a, Figure 11.2b).

The Department of Health operates a website called "Onde está o Aedes?" (Where is the Aedes?), which provides maps with information about the presence 


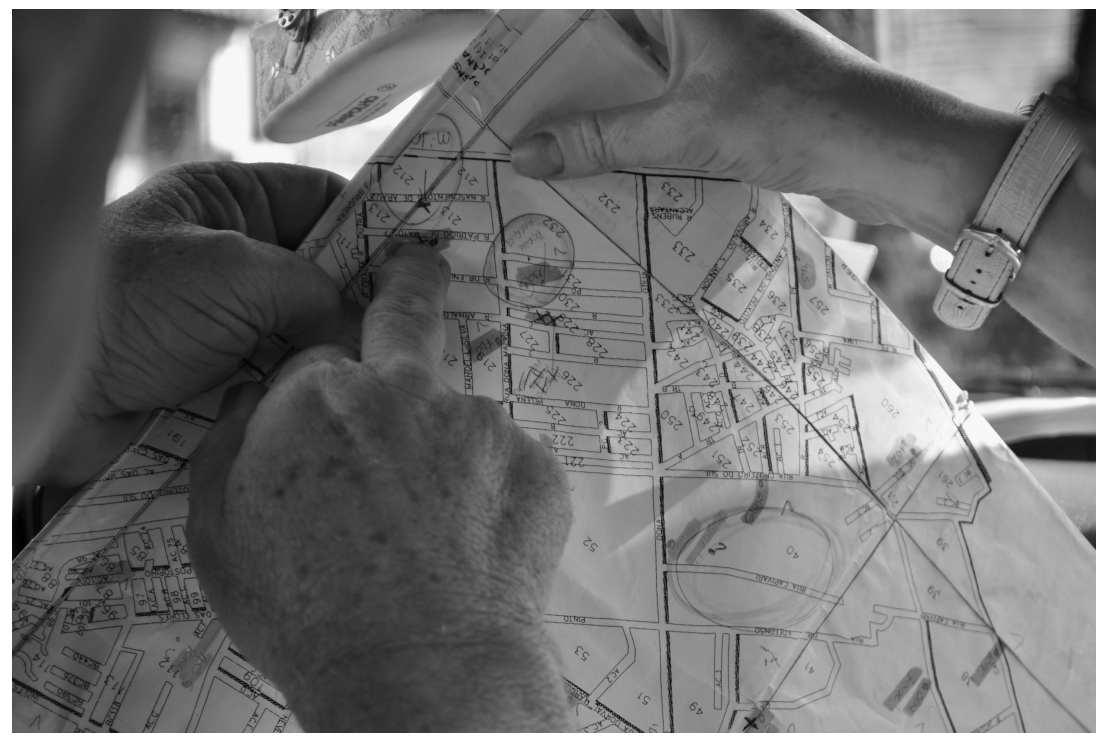

FIGURE 11.1 Mosquito workers planning an intervention in Porto Alegre, May 2018. Photograph by Jean Segata.

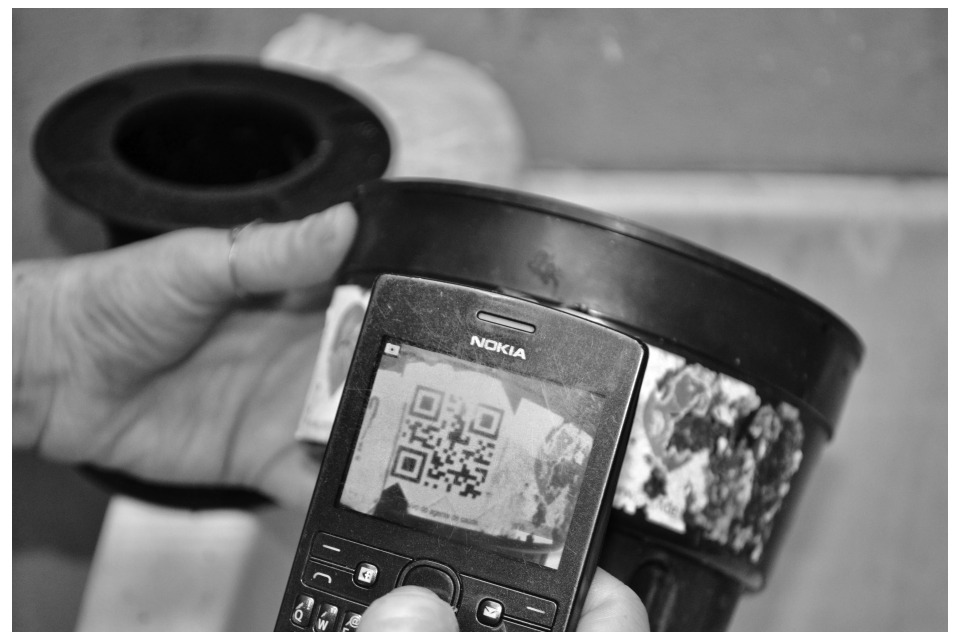

FIGURE 11.2A Inspecting a mosquito trap in Porto Alegre, May 2018. Photograph by Jean Segata.

of mosquitoes and viruses: Zika, dengue, chikungunya and, recently, yellow fever as well. In addition, the website presents tables and graphs with information about the origins of the virus in various locations: when it appeared, and whether humans were infected, or just mosquitoes. "The mosquito is our partner," Ligia told me. "People must learn to live with them. You can see on the map, our 


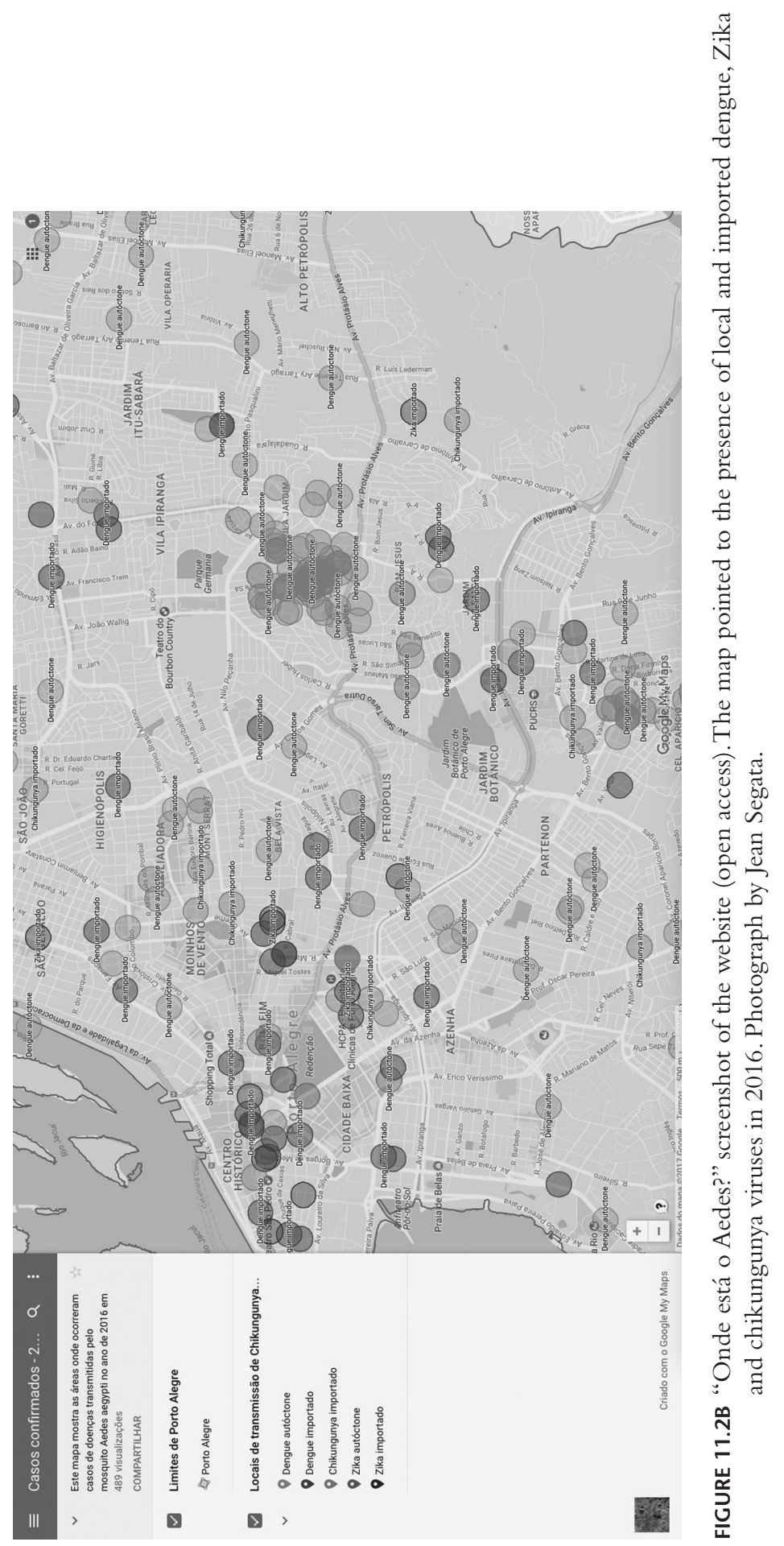


mosquitoes are healthy and they help us fight the virus," Ligia explained: in Porto Alegre, the mosquito was even deemed a sort of prophet, by providing a set of indices that may predict epidemics.

Using mosquitoes to predict epidemics reflects a recent trend in science that relies on plants and animals to be sentinels for supporting biosecurity policies (Keck 2009, 2020, Lakoff 2015, 2017). Reports of sick monkeys, observations of behavioural changes in birds, reports of problems with plants and marine creatures - all serve as indicators of possible epidemics, environmental disasters or climatic changes. Of course, the illnesses of human beings also provide warning signs: avian and swine flu, mad cow disease, pneumonic plague, Leishmaniasis and problems with so-called invasive species-all these issues determine the shape of the political, moral and epistemological debates that involve animals, human health, their infrastructures and environments (Caduff 2014a, Keck 2010, Nading 2014). Keeping such issues in mind, social anthropologists have developed the idea of "multispecies ethnography" with the aim of placing at the centre of attention those creatures that were formerly maintained at the margins (Kirksey \& Helmreich 2010, Tsing 2012). As a result, “animals, plants, fungi and microbes once confined in anthropological accounts to the realm of zoe or 'bare life'-that which is killable-have started to appear alongside humans in the realm of bios, with legibly biographical and political lives (Kirksey \& Helmreich 2010: 545-546, emphasis mine). Thus, next to Lévi-Strauss's encyclopaedic animals are "good to think" and Marvin Harris's materialistic animals are "good to eat," we now have the opportunity to take lessons from Donna Haraway's (2007) suggestion that "animals are good for living together." Porto Alegre mosquitoes have been converted into co-workers helping health authorities to find viruses. Taking them seriously can be very useful in studying humans in society.

Despite such developments in human-animal relations, the government's new digital tools of epidemic intelligence still operate in the same top-down tradition that hierarchizes knowledge and practices. They are derived from applied science, and form a type of laboratorial experiment spread across the world (Segata 2018b). Professional decisions about public health are guided largely by theoretical and methodological choices rooted in techno-scientific assumptions than by rich analyses of individual environments, indigenous knowledge, local practices and tried-and-tested experiences. The most affected populations are often not part of public policy-making, but rather mandatory partners in their implementation. Digitalization and geneticization lead to molecularizing and squelching of relations (Rabinow 1996, Fischer 2003, Rose 2013). In Natal and Porto Alegre alike, digital logic_-based on DNA scans and binary codes-shapes the devices meant to define relations between humans, mosquitoes and their environments (Segata 2018a).

It should be noted, finally, that technologies serve to separate people from people, but they also separate people from other beings, artefacts and moral regimes. As Antina von Schnitzer (2013) argues, practices go beyond specific projects and therefore must be made sensitive to the political and creative sides of 
technologies. I first heard about the “Onde está o Aedes?” website when I went to live in Porto Alegre in 2016. When searching for an apartment there, I was told by a real estate broker that the Moinhos de Vento neighbourhood would be a good choice. At his office, the broker turned to his laptop, and pointing to the government map said: "Look on the screen, here you're going be free of mosquitoes. It's always green." The small inconsistency, though, is that no traps are set in Moinhos de Vento. Both in Porto Alegre and Natal, traps are not placed in prosperous neighbourhoods. Authorities do indeed find mosquitoes, but exactly where they want to find them: among poor people.

\section{Recalcitrance, uncertainties and futures}

"You gotta find the enemy before it finds you," Ligia told me in an effort to justify her software, data-mining systems and PCR budget. "You must always be prepared ... As long as there are mosquitoes, there will be new biosecurity products." What she said reinforces the impression that biosecurity emerges as a global project for converting public health into a security issue. The merging of health and safety and the scaling up of the production of biosecurity goods and services has often been justified by a flexible idea of globalization: presumably, the expanding production of animal and vegetable products and their international trade-together with the global circulation of human beings-necessitate it, with modern microbiology facilitating it. This explanation, however, is not the whole story, and other explanations come to mind.

For Stephen Collier (2011), there is a tendency to transfer public health to a state of mind that almost disappeared at the end of the Cold War. This tendency to conflate safety with health was enhanced during the emergence of influenza in the early twentieth century, especially avian and swine flus, but also Ebola and more recently Zika and the COVID-19 pandemic. The global economy's vulnerability to terrorism materialized not only in the 2001 attack on the Twin Towers, but also in the bioterrorism manifested in anthrax letters dispatched the same year. Spurred on by speeches promising catastrophes, these events revived an imagery of threats ranging from nuclear bombs to mutant and antibiotic-resistant superbugs or deadly strains of a sleeping virus able to cross oceans on commercial aircraft (Caduff 2014a). Biosecurity launched a variety of messages: in Europe, the term became linked to food security and the handling of agricultural and livestock products; in Australia, biosecurity signified reducing negative effects of invasive species; and in the United States, the term addressed dangers of human contamination by biological agents, whether from zoonotic diseases or the pathogens of bioterrorism (Bingham \& Hinchliffe 2008). Biosecurity policies and practices are typically woven within local contexts, although they almost always import problems and solutions from the Global North to the Global South. In the end, events described as threats on a global scale have mobilized new economies of risk, prevention and response to epidemics. Biosecurity is the buzzword that health capitalism uses to fuse health and security into a single commodity (Segata 2020). 
The Aedes aegypti mosquito is one of the most sophisticated technologies created by tropical medicine since it causes epidemics (Benchimol 2001, 2011, Segata 2018a). For more than 100 years, this mosquito has been widely known to transmit the viruses of yellow fever and dengue, and more recently those of chikungunya and Zika. This little insect has subsequently become part of the infrastructure of science and health policies (Löwy 2006, Segata 2018a): although the diseases are quite different, they are all shaped by mosquitoes; accordingly, most public health policies surrounding these diseases rely on the monolithic method of killing mosquitoes with pesticides (Augusto et al. 1998). Mosquito-centrism is the principal symptom of our health policies. It is as persistent as the militarization of those policies.

The discovery of the mosquito's role as a disease vector went hand in hand with the beginning of US interventions in Latin America. The movement for the independence of Cuba and the construction of the Panama Canal provide two examples: in both cases, yellow fever began killing people. So, when General William Gorgas took action against the disease, the mosquito became an enemy and the war against it began: enemies and warfare, but also territories, campaigns, mapping, control, combat and struggle (Espinosa 2009, Löwy 2006, 2017, McNeill 2010, Stepan 2011). Military semantics were everywhere, and they were especially prevalent when the Rockefeller Foundation led the great campaign against yellow fever in Latin America from the 1920s to the 1950s, with the secret weapon unveiled as DDT. It sought to "kill the enemy before it killed us." Rockefeller Foundation experts established an international standard known as the "mosquito index" which measured the effectiveness of health programmes based on the link between mosquito habitats and human habits. Based on this logic, efficient mosquito control involved surveillance and joint control of humans, the insects that preyed upon them, and the territories they both shared (Löwy 1990, 1996, 1999, 2006, Segata 2017).

In the lexicon of an epidemic, the virus is an "invisible enemy," a "terrorist" that must be "fought." In arming themselves to defeat this microscopic enemy, epidemiologists must turn on the vector, for it has wings and can be neutralized with the push of a spray nozzle. The mosquito therefore becomes enemy number one, because it can be attacked. The metric tons of poison, the heaps of dead animals, the transformed environments are the war-torn landscapes of an extended mosquito battle, still not won.

This imagery is even older. Before the mosquito, theories of miasmas and contagion supported hygienist policies in Latin America and the Caribbean. In Rio de Janeiro, sanitary policies led to the destruction of cortiços, or dense housing developments: poor and black people were persecuted and expelled from city centres under the accusation that they were dirty and dangerous (Figure 11.3a, Figure 11.3b). Pasteurian theories led Oswaldo Cruz and his colleagues to force vaccinations on the population and invade private homes to apply pesticides (Benchimol 1992, 2001, 2003, Chalhoub 1993, 2013). Social politics reinforced microbial politics: as humans, their bodies and territories came to be controlled 


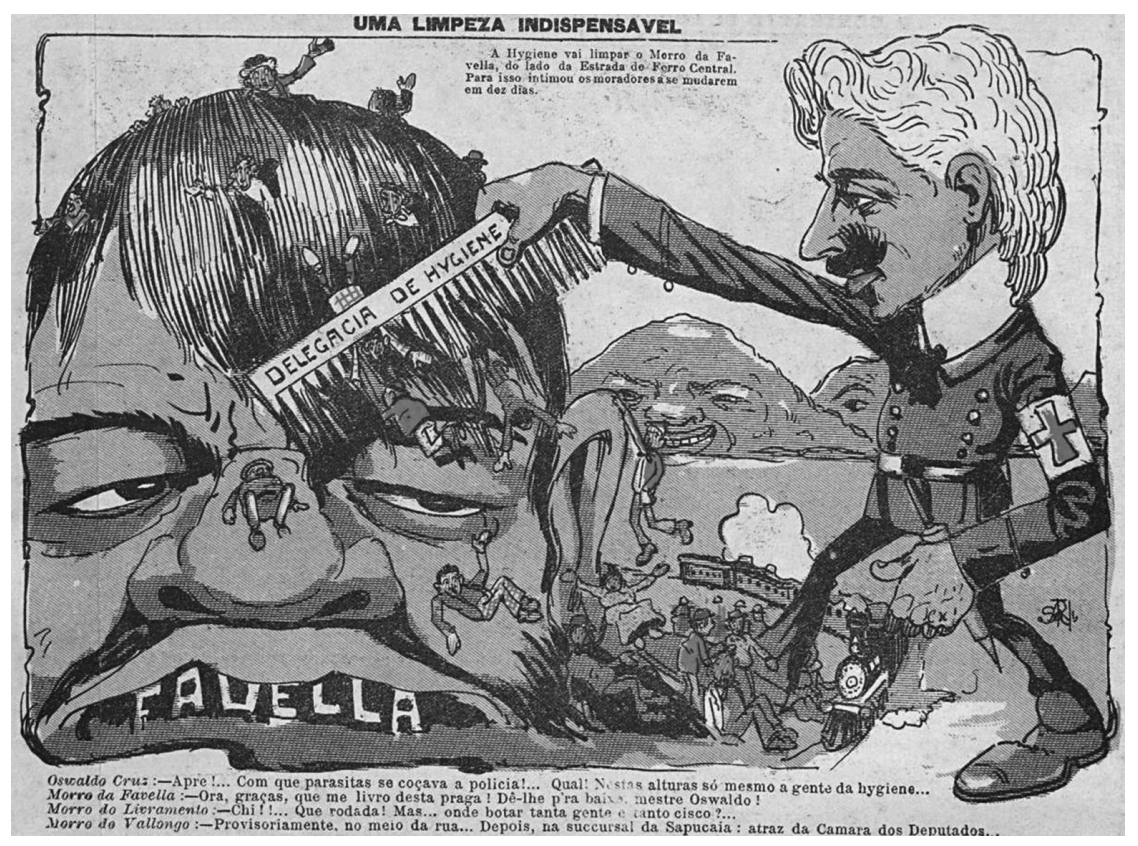

FIGURE 11.3A Caricature of Oswaldo Cruz "cleaning up" the Morro da Favela (Rio de Janeiro) published in Jornal O Malho, 8 June 1907. The criticism was that sanitary policies classified poor people and microbes as threats to the development of the nation. Unknown author.

by the state at the end of nineteenth century; microbes revealed by Pasteur would also come under state control. Hygienists and government employees established standards for what they believed to be "pure" social relations, that is, relations that would not be derailed by microbial eruptions, relations that could be predicted, and therefore rationally ordered (Paxson 2008).

The point is that despite DNA and new digital technologies, policies act in the same exclusionary manner as they did a century ago. Geolocation of breeding sites supports the maintenance and the production of distorted moralities and heightened inequalities (Segata 2016a, 2016b). In Natal, the lack of running water in poor neighbourhoods means that people must store water in buckets, where mosquitoes lay eggs. But referring only to the presence of mosquitoes takes an infrastructural issue and renders it an issue of personal responsibility amongst the poor. I found that during my fieldwork, personal responsibility for mosquitoes caused tense situations in which declarations about "the neighbour's mosquitoes" or "people with the red spot" became accusatory categories. Living in a red-designated area is an accusation of being dirty-and hence having both one's physical property and social status devalued. 


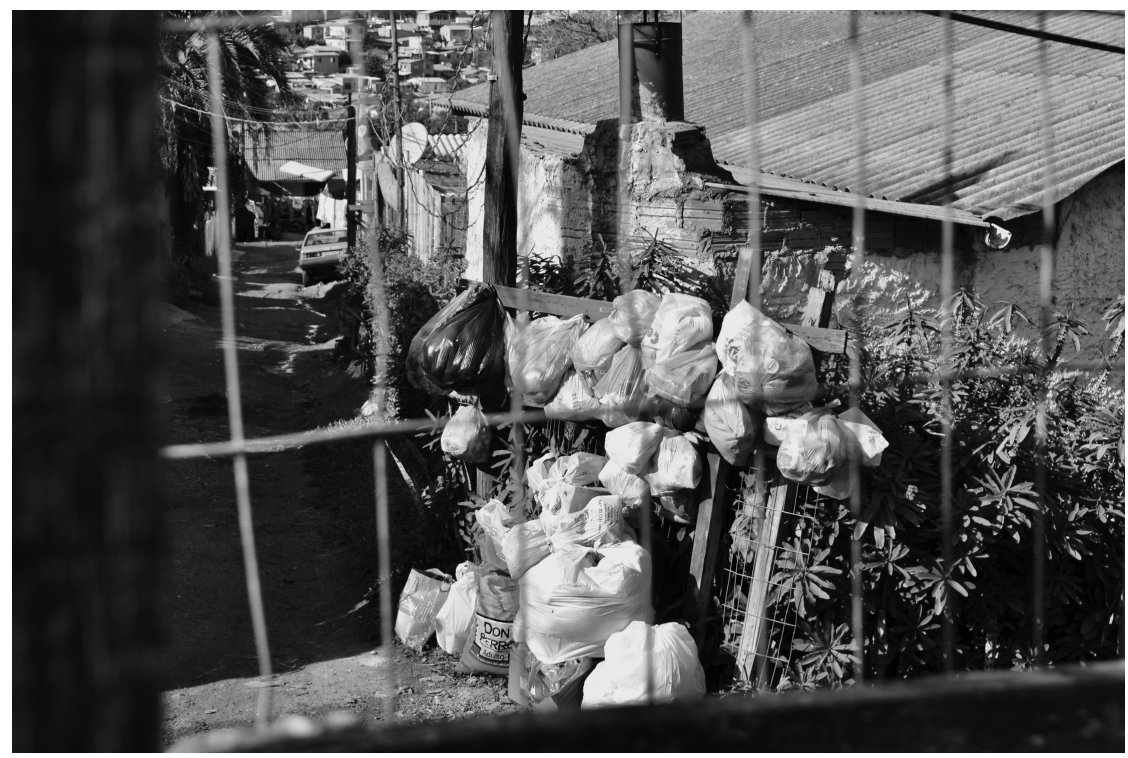

FIGURE 11.3B Current situation in low-income communities in Brazil. Area with mosquito breeding spots in Porto Alegre, May 2018. Photograph by Jean Segata.

The outcome is that the mere act of control or testing of a house for mosquitoes is conceived as a threat. As Lucas once said,

You must go from door to door and hunt the mosquito, but people don't like it ... They become furious because they think we're accusing them of being the "owners of the mosquito." They're just living their lives, and we're just doing our mission, but people think we're persecuting them because they might be dirty and guilty. It's not true, but I don't get involved: I don't want to take a bullet—something which has happened.

(Lucas, mosquito worker. Natal, November 2015)

In Natal, simply receiving a visit makes one into a "polluter," meaning that this person is the reason others get sick. As Lucas mentioned, conflicts are common, including violence against health agents (Segata 2017). Moreover, the virtual software makes the actual suffering invisible. The software never touches the ground and requires no physical protection, while the workers do. All the workers I lived with in Natal had already fallen ill with dengue, Zika or chikungunya. They were not given repellent, appropriate clothing, even sunscreen, and the poisons they used were also handled without gloves (Segata 2018b). 


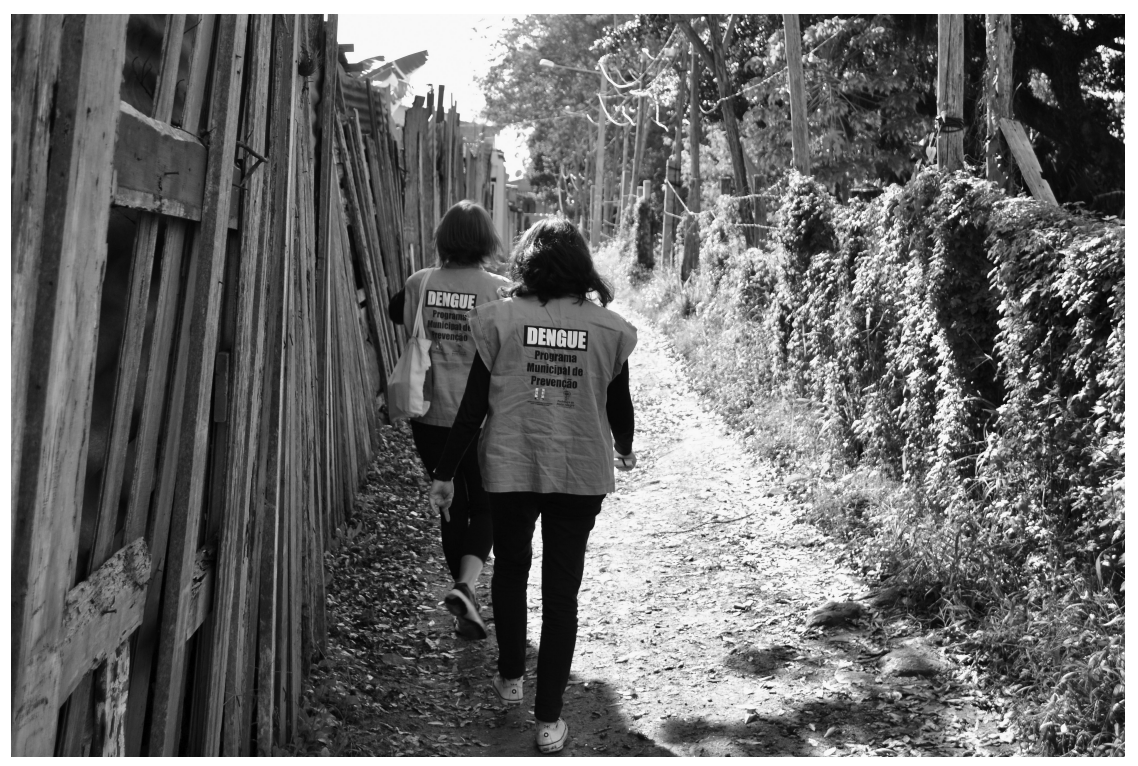

FIGURE 11.4 Doing fieldwork among mosquito workers. Porto Alegre, May-June 2018. Photograph by Jean Segata.

In Porto Alegre, the government has implemented one of the most innovative public policies in Brazil by controlling disease through sequencing mosquito DNA. The technology is enchanting, but it contrasts dramatically with the fact that in one of the Brazilian cities with the highest per capita income, $44 \%$ of the population still do not have basic sanitation (Segata 2018b). Porto Alegre uses PCR for identifying mosquitoes, but lacks the most basic infrastructure of sealed and separated pipes for carrying drinking water and sewage. Although mosquito traps here are placed only in poor areas, some of the people who get sick live in wealthy neighbourhoods. Ashamed of getting "a poor person's disease," these dengue victims often hide being sick (Figure 11.4).

The other health workers in Porto Alegre that help locate viruses are the mosquitoes. Their terms of work are harsh: after all, some of them get caught in traps, and if they're found alive, they are usually crushed with the tip of a toothpick, intubated, and centrifuged in a laboratory to finish their careers as "genetic material" on a microscope slide. Sentient as they may be, mosquitoes nonetheless become a killable otherness. They do not receive the same respect as dogs suffering from Leishmaniasis, whose conviviality and contagion mobilize broad efforts of care and moral debate (Lewgoy et al. 2020). Mosquitoes are hardly animate creatures, and certainly not "persons" like dogs. They don't even have a face, as Lévinas (1984) might point out - and therefore they do not deserve moral consideration.

But mosquitoes are resistant. They are like the mushrooms that Anna Tsing describes in her travels: unruly (Tsing 2005, 2012). They remind us that we are 
not always in control. When one considers the yellow fever that killed Europeans who reached the warm sands of Latin America and the Caribbean, one realizes that mosquitoes were the first anti-colonialists (McNeill 2010). They resisted America's whitening, as well as the pesticide industry and global health imperialism. They always come back-even if it may take a while-and they make policy managers a little worried when they do not reappear immediately. Too much or too little rain may destroy their eggs, for example. Carlos complained about this when I asked him about yellow fever in Natal: "The mosquitoes were not collaborating that year," he explained. The epidemic investigation might fail. Sometimes mosquitoes are not very skilled with politics.

A lack of mosquitoes seems like a good sign, except for the mosquito workers and professional politicians. These both need the "mosquito's salary" to live, and without mosquitoes, budgets are not renewed. Beyond any dreams of control or eradication, health authorities must convince the federal government that mosquitoes still pose a threat. There is a political calculation to be made, and that is why computer models use historical information to predict future scenarios. A virtual catastrophe of an uncertain tomorrow, based on data from the past, justifies the costs and the structures of the present. The "struggle" is not about prevention, but about production and action on what is uncertain, always ready to get out of control. Uncertainty has become a subject of its own in global health policy. "Being alert and prepared" is a condition of suspending the present to create "the promise of infrastructure" (Appel et al. 2018). Such infrastructure produces expectations, allocates life - and in my case-offers false certainties in the form of digital technologies and genetic codes.

\section{Conclusions}

Beyond declarations of control and eradication, human-mosquito relations in Brazil are manifested in politics. New technologies and practices support a complex space of power. DNA and algorithms work on the same mathematical principle, and both may be expressed digitally: software or combinations of acids and proteins inscribe realities supported by confidence in computational calculation and in the universal materiality of biology. Although the world is not digital, our modern way of managing it has become so. Yet we cannot confuse genetic and computational modelling with life itself.

Digital life technologies are integral to new global infrastructures of health capitalism, manifested in information packages such as those used in Natal and Porto Alegre. At the beginning of the twentieth century, the internationalization of public health was based on technologies aimed at killing microbes; today, it is time to sell powerful global programmes aimed at managing local public policies. The goal for public health is still the same: surveillance and control of populations and territories. Now, however, the interest shifts from preventing widespread risk to "predicting enacted threats." These associated intelligences do not prevent epidemics from happening, but they do predict a future for which 
we must prepare. A large task of health workers is to produce data to feed to predictive technologies, rather than acting on concrete problems of the present. As Gerda Reith (2004) explains, risk helps us to colonize the future-with ongoing anti-mosquito policies depending precisely on this. The problem is that for all of this to function, "everyone must do their part," including, of course, people, but also mosquitoes, epidemiology, entomology, algorithms and viruses. As my colleague Carlos once concluded,

"mosquitoes are a gold mine and each epidemic is a blank check. But they have to be more discreet and collaborate with us: if we show up too much, we must kill them; but if they are eradicated, the money won't come".

(Carlos, mosquito worker. Natal, November 2015)

A lot of information has been produced by the intel of these new epidemics: maps, indexes, historical series, data sets that promise predictive ability and best response. But when monkeys started to die in Natal, mosquito workers did not know if yellow fever was coming back. The time of the disease did not coincide with the time of information, much less with that of bureaucracy. Digitalized and prophet mosquitoes are not always able to foresee new epidemics. They nonetheless help in predicting budgets that support the continuity of the few public health policies. In the right quantities, they are good partners.

\section{Notes}

1 This chapter is based on a talk presented at the Princeton University in December 2018. I am grateful to João Biehl for the invitation, and to Alex Nading and Amy Moran-Thomas for comments during the writing. I am also grateful to Jessica Leinaweaver for the support and favourable environment for teaching and research during my stay at the Center for Latin American and Caribbean Studies at Brown University, and to Andrea Mastrangelo at the Centro Nacional de Diagnóstico e Investigación en Endemoepidemias - CeNDIE of the Ministry of Health, Argentina. The research was supported with grants from CNPq (The Brazilian National Council for Scientific and Technological Development) and from CONICET (National Scientific and Technical Research Council of Argentina). An earlier version of this chapter was published in Spanish in the Colombian Journal Tabula Rasa (Segata 2019).

2 In this context, an important guide to my work is the intersection of ideas as "architectures of domestication" in David Andersons et al.s (2017), also the idea of "infrastructure" as used by Susan Star (1999) and Bryan Larkin (2013) and of the "ontological politics" of Annemarie Mol (1999). Infrastructure refers to a subtle apparatus of governmentality that includes artefacts, institutions, discourses and knowledge (Star 1999). The elements that form these apparatuses cannot be reduced to a type of neutral stage where science and politics take place-before this, an infrastructure is also political (and makes politics).

\section{Bibliography}

Anderson, D., et al. 2017. Architectures of domestication: On emplacing humananimal relations in the North. Journal of the Royal Anthropological Institute, 23(2): $398-416$. 
Appel, H., Anand, N., Gupta, A. 2018. Introduction: Temporality, politics, and the promise of infrastructure. In Anand, N., Gupta, A., Appel, H., eds. The Promise of Infrastructure. Durham: Duke University Press, 1-41.

Augusto, L., Torrez, J.P., Costa, A., Pontez, C., Novaez, T. 1998. Programa de erradicação do Aedes aegypti: Inócuo e perigoso (e ainda perdulário). Cadernos de Saúde Pública, 14(4): 876-877.

Benchimol, J. 1992. Pereira Passos —um Haussmann Tropical: A renovação urbana do Rio de Janeiro no início do século XX. 2a. ed. Rio de Janeiro: Secretaria Municipal de Cultura, Turismo e Esportes.

Benchimol, J. 1999. Dos micróbios aos mosquitos: Febre amarela e a revolução pasteuriana no Brasil. Rio de Janeiro: EdUFRJ/Editora Fiocruz.

Benchimol, J. 2001. Febre amarela: A doença e a vacina, uma história inacabada. Rio de Janeiro: Editora Fiocruz.

Benchimol, J. 2003. Reforma urbana e revolta da vacina na cidade do Rio de Janeiro. In Ferreira, J., Neves, A., eds. O Brasil republicano: Economia e sociedade, poder e política, cultura e representações. Rio de Janeiro: Civilização Brasileira, 231-286.

Benchimol, J. 2011. Mosquitos, doenças e ambientes em perspectiva. Anais do XXVI Simpósio Nacional de História. São Paulo: ANPUH, 1-15.

Bingham, N.; Hinchliffe, S. 2008. Mapping the multiplicities of biosecurity. In Collier, S., Lakoff, A., eds. Biosecurity Interventions: Global Health and Security in Question. New York: Columbia University Press, 173-194.

Biehl, J., Amon, J.J., Socal, M.P., Petrina, A. 2012. Between the court and the clinic: Lawsuits for medicines and the right to health in Brazil. Health and Human Rights: An International Journal, 14(1): 1-17.

Biehl, J. 2013. The judicialization of biopolitics: Claiming the right to pharmaceuticals in Brazilian courts. American Ethnologist, 40(3): 419-436.

Brasil. 2005. Ministério da Saúde, Secretaria de Vigilância em Saúde, Diretoria Técnica de Gestão. Diagnóstico rápido nos municípios para vigilância entomológica do Aedes Aegypti no Brasil LIRAa: Metodologia para os índices Breteau e Predial. Brasília: Ministério da Saúde.

Brasil. 2009. Ministério da Saúde, Secretaria de Vigilância em Saúde, Departamento de Vigilância Epidemiológica. Diretrizes nacionais para a prevenção e controle de epidemias de dengue. Brasília: Ministério da Saúde.

Caduff, C. 2014a. On the verge of death: Visions of biological vulnerability. Annual Review of Anthropology, 43: 105-21.

Caduff, C. 2014b. Sick weather ahead: On data-mining, crowd-sourcing and white noise. Cambridge Anthropology, 32(1): 32-46.

Caduff, C. 2015. The Pandemic Perhaps: Dramatic Events in a Public Culture of Danger. Berkeley: University of California Press.

Chalhoub, S. 1993. The politics of disease control: Yellow fever and race in Nineteenth Century Rio de Janeiro. Journal of Latin American Studies, 25: 441-463.

Chalhoub, S. 2013. A cidade febril: Cortiços e epidemias na corte imperial. São Paulo: Companhia das Letras.

Collier, S. 2011. Post-Soviet Social: Neoliberalism, Social Modernity, Biopolitics. Princeton: Princeton University Press.

Collier, S., Lakoff, A. 2008. The problem of securing health. Mapping the multiplicities of biosecurity. In Collier, S., Lakoff, A., eds. Biosecurity Interventions: Global Health and Security in Question. New York: Columbia University Press, 7-32.

Escobar, A. 2016. Bem-vindos à Cyberia: Notas para uma antropologia da cibercultura. In Segata, J., Rifiotis, T., eds. Políticas etnográficas no campo da cibercultura. Brasília: ABA Publicações, 21-66. 
Espinosa, M. 2009. Epidemic Invasions: Yellow Fever and the Limits of Cuban Independence, 1878-1930. Chicago: University of Chicago Press.

Fassin, D. 2013. Enforcing Order: An Ethnography of Urban Policing. Malden: Polity Press.

Fischer, M. 2003. Emergent Forms of Life and the Anthropological Voice. Durham: Duke University Press.

Hacking, I. 2002. L'émergence de la Probabilité. Paris: Seuil, 2002.

Haraway, D. 2007. When Species Meet. Minneapolis: University of Minnesota Press.

Keck, F. 2009. Conflits d'experts: Les zoonoses, entre santé animale et santé humaine. Ethnologie française, XXXIX(1): 79-88.

Keck, F. 2010. Un monde grippé. Paris: Flammarion.

Keck, F. 2020. Avian reservoirs: Virus hunters and birdwatchers in Chinese sentinel posts. Durham: Duke University Press.

Kirksey, E., Helmreich, S. 2010. The emergence of multispecies ethnography. Cultural Anthropology, 25(4): 545-576.

Lakoff, A. 2008. From population to vital system: National security and the changing object of public health: Mapping the multiplicities of biosecurity. In Collier, S., Lakoff, A., eds. Biosecurity interventions: Global Health and Security in Question. New York: Columbia University Press, 33-61.

Lakoff, A. 2015. Real-time biopolitics: The actuary and the sentinel in global public health. Economy and Society, 44(1): 40-59.

Lakoff, A. 2017. Unprepared: Global Health in a Time of Emergence. Berkeley: University of California Press.

Larkin, B. 2013. The politics and poetics of infrastructure. Annual Review of Anthropology, 42: 327-343.

Latour, B., Woolgar, S. 1997. A Vida de laboratório: A produção dos fatos científicos. Rio de Janeiro: Relume Dumará.

Lévinas, E. 1984. Éthique et Infini. Paris: Le Livre de Poche.

Lewgoy, B., Mastrangelo, M., Beck, L. 2020. Tanatopolítica e biossegurança: Dois regimes de governo da vida para a Leishmaniose Visceral Canina no Brasil. Horizontes Antropológicos, 26(57): 145-176.

Löwy, I. 1990. Yellow fever in Rio de Janeiro and the Pasteur Institute Mission (19011905): The transfer of science to the periphery. Medical History, 34: 144-163.

Löwy, I. 1996. Éradication de vecteur contre vaccination: La Fondation Rockefeller et la fièvre jaune au Brésil, 1923-1939. In Waast, R., ed. Médicenes et santé (Les sciences hors d'Occident au XXe Siècle - Vol. 4). Paris: Orstom Édition/IRD, 91-108.

Löwy, I. 1999. Representação e intervenção em saúde pública: Vírus, mosquitos e especialistas da Fundação Rockefeller no Brasil. História, Ciências, Saúde - Manguinhos, 3 : 647-677.

Löwy, I. 2006. Virus, mosquitos e modernidade: A febre amarela no Brasil entre ciência e política. Rio de Janeiro: Editora Fiocruz.

Löwy, I. 2017. Leaking containers: Success and failure in controlling the mosquito Aedes aegypti in Brazil. American Journal of Public Health, 107(4): 517-524.

MacPhail, T. 2014. The Viral Network: A Pathography of the H1N1 Influenza Pandemic. Ithaca: Cornell University Press.

Mason, K. 2016. Infectious Change: Reinventing Chinese Public Health after an Epidemic. Stanford: Stanford University Press.

McNeill, J.R. 2010. Mosquito Empires: Ecology and war in the Greater Caribbean, 1620-1914. Cambridge: Cambridge University Press.

Mol, A. 1999. Ontological politics: A word and some questions. In Law, J., ed. Actor Network Theory and after. London: Blackwell, 74-89. 
Nading, A. 2014. Mosquito Trails: Ecology, Health and the Politics of Entanglement. Berkeley: University of California Press.

Natal. 2015.Vigi@dengue: nova abordagemna vigilância de dengue e outras arboviroses no município de Natal. Natal: Secretaria Municipal de Saúde, Departamento de Vigilância em Saúde, Centro de Controle de Zoonoses (PowerPoint presentation).

Paxson, H. 2008. Post-Pasteurian cultures: The microbiopolitics of raw-milk cheese in the United States. Cultural Anthropology, 23(1): 15-47.

Rabinow, P. 1996. Making PCR: A Story of Biotechnology. Chicago: University of Chicago Press.

Reis-Castro, L., Heidrickx, K. 2013. Winged promises: Exploring the discourse on transgenic mosquitoes in Brazil. Technology in Society, 35: 118-128.

Reith, G. 2004. Uncertain times: The notion of 'risk' and the development of modernity. Time \& Society, 13(2-3): 383-402.

Rose, N. 2013. A política da própria vida: Biomedicina, poder e subjetividade no Século XXI. São Paulo: Paulus.

Secretaria Municipal de Saúde. 2015. Secretaria municipal de Saúde, Departamento de Vigilância em Saúde, Centro de Controle de Zoonoses.Vigi@dengue: Nova abordagem na vigilância de dengue e outras arboviroses no município de Natal. Natal, (mimeo).

Segata, J. 2016a. A doença socialista e o mosquito dos pobres. Iluminuras, 17(42): 372-389.

Segata, J. 2016b. Os mosquitos vilões e as casas de ponta de lápis. VI Congresso da Associação Portuguesa de Antropologia. Coimbra.

Segata, J. 2017. O Aedes aegypti e o digital. Horizontes Antropológicos, 48(23): 19-48.

Segata, J. 2018a. Virus, algorithmics and DNA: Anthropology and new epidemics intelligence. Symposium - Global Epidemics, Local Anthropologies? 18th IUAES World Congress, Florianópolis.

Segata, J. 2018b. Cuando la epidemia nos viola. Seminario Internacional Convivencia y contágio: El rol del antropólogo en las relaciones sociedad-naturaleza-enfermidad. Argentina: IDAES, Universidad Nacional de San Martin.

Segata, J. 2019. El mosquito-oráculo y otras tecnologías. Tabula Rasa, 32: 103-125.

Segata, J. 2020. Covid-19, biossegurança e antropologia. Horizontes Antropológicos 26(57): 275-313.

Star, S. 1999. The ethnography of infrastructure. American Behavioral Scientist, 43(3): 377-391.

Stepan, N. 2011. Eradication: Ridding the World of Diseases Forever? London: Reaktion Books.

Tsing, A. 2005. Friction: An Ethnography of Global Connection. Princeton: Princeton University Press.

Tsing, A. 2012. Unruly Edges: Mushrooms as Companion Species: For Donna Harraway. Environmental Humanities, 1: 141-154.

Vargas, E. 2018. Mosquitos, armadilhas e vírus: etnografia de uma política pública de controle ao Aedes aegypti. Dissertação (Mestrado). Instituto de Filosofia e Ciências Humanas, Programa de Pós-Graduação em Antropologia Social. Porto Alegre: Universidade Federal do Rio Grande do Sul.

Von Schnitzer, A. 2013. Traveling Technologies: Infrastructures, ethical regimes, and the materiality of politics in South Africa. Cultural Anthropology, 8(4): 670-693. 